\title{
Analisa Teknis dan Ekonomis Pembangunan Galangan Kapal Pengangkut LNG Ukuran Kecil (Small Scale LNG Carrier) untuk Perairan Indonesia
}

\author{
Rizain Andrian dan Triwilaswandio Wuruk Pribadi \\ Departemen Teknik Perkapalan, Fakultas Teknologi Kelautan, Institut Teknologi Sepuluh Nopember (ITS) \\ e-mail: triwilas@na.its.ac.id
}

\begin{abstract}
Abstrak-Indonesia adalah negara kepulauan yang memiliki lautan luas dan perairan yang menghubungkan setiap pulaunya. Pada beberapa pulau yang jauh dari pusat pertumbuhan ekonomi masih kesulitan mendapatkan sarana listrik karena lokasi tersebut tidak terhubung dengan jaringan listrik utama. Pemerintah melalui program 35.000 MW berencana membangun pembangkit listrik di beberapa daerah tersebut dan menggunakan LNG sebagai bahan bakarnya. Small Scale LNG Carrier menjadi solusi yang paling tepat untuk mendistribusikan LNG ke lokasi tujuan baik secara teknis maupun ekonomis. Selain karena faktor ukuran LNG Carrier yang tidak cocok untuk kondisi geografis Indonesia, penggunaan pipa gas tidak feasible untuk dibangun pada lokasi yang dituju. Dengan banyaknya pasar untuk untuk penggunaan LNG sebagai bahan bakar pembangkit listrik, dibutuhkan kapal dengan jumlah yang cukup banyak untuk membantu distribusinya. Saat ini, di Indonesia belum ada galangan kapal yang dapat memproduksi Small Scale LNG Carrier. Oleh karena itu, perlu dilakukan analisa teknis dan ekonomis pembangunan galangan kapal Small Scale LNG Carrier di Indonesia dengan memperhitungkan aspek pasar, standar pembangunan kapal, dan kelayakan investasi untuk proyek tersebut. Hasil dari analisa kelayakan investasi adalah diperlukan biaya sekitar 341 milyar rupiah untuk pembangunan galangan kapal Small Scale LNG Carrier dan perkiraan Payback Period pada tahun ke-9 bulan ke-1,5 dengan nilai Net Present Value (NPV) sebesar 82,3 miliar rupiah, Internal Rate of Return (IRR) sebesar $13,41 \%$ lebih besar dari bunga bank yang telah ditetapkan, yaitu $11 \%$. Sehingga investasi untuk pembangunan galangan kapal Small Scale LNG Carrier layak dilakukan.
\end{abstract}

Kata Kunci-LNG, Small Scale LNG Carrier, galangan kapal, Indonesia, pembangkit listrik, kelayakan investasi

\section{PENDAHULUAN}

$\mathrm{P}$ ASAR baru untuk gas alam berkembang pesat dengan potensi yang dimilikinya sebagai sumber energi bersih. Gas alam memiliki karakteristik tidak berwarna, tidak berbau, tidak beracun, dan ramah lingkungan yang tentunya berguna untuk mengurangi tingkat emisi dunia. Gas alam tidak hanya ramah lingkungan tetapi dari segi ekonomis belakangan ini jauh lebih menguntungkan dari minyak. Indonesia adalah negara yang kaya akan sumber energi dan dulunya merupakan salah satu negara pengekspor gas alam terbesar di dunia. Belakangan ini gas alam dimanfaatkan penggunaannya di dalam negeri sebagai bahan bakar pembangkit listrik di beberapa daerah yang tidak terhubung dengan jaringan listrik utama dan kedepannya seluruh produksi gas alam di Indonesia akan dimanfaatkan secara optimal untuk memenuhi kebutuhan pasar dalam negeri. Untuk mempermudah distribusi dari satu tempat ke tempat lainnya, maka gas alam ini dikonversi menjadi gas alam cair atau biasa disebut dengan Liquefied Natural Gas (LNG) yang dapat diangkut lewat laut dengan menggunakan LNG Carrier. LNG telah menjadi solusi pasar yang sebelumnya tidak dapat dijangkau oleh saluran pipa gas, yaitu sebagai bahan bakar transportasi dan pembangkit listrik untuk daerah yang tidak terhubung dengan jaringan listrik utama. [1]

LNG Carrier reguler merupakan kapal pengangkut LNG yang berkapasitas 125.000 - $266.000 \mathrm{~m}^{3}$, berbeda dengan Small Scale LNG Carrier yang memiliki kapasitas $1.000-40.000 \mathrm{~m}^{3}$. [2] LNG Carrier cocok digunakan untuk distribusi LNG antar negara yang beroperasi di perairan internasional, sedangkan untuk distribusi di daerah antar pulau seperti Indonesia lebih tepat menggunakan Small Scale LNG Carrier karena LNG Carrier berukuran reguler tidak bisa masuk ke lokasi tersebut. Oleh karena itu, Small Scale LNG Carrier diperlukan untuk mengangkut LNG ke lokasi-lokasi terpencil yang ada di Indonesia. [3]

Saat ini pembangunan kapal pengangkut LNG baik LNG Carrier maupun Small Scale LNG Carrier hanya bisa dilakukan di luar negeri karena kapal tersebut memiliki teknologi tinggi yang belum mampu dikuasai oleh galangan kapal nasional. Maka dari itu, pembangunan Small Scale LNG Carrier di galangan kapal dalam negeri perlu dilakukan untuk memajukan industri galangan kapal nasional dan membantu kebutuhan distribusi LNG di Indonesia pada masa mendatang khususnya di daerah-daerah yang membutuhkan gas alam sebagai bahan bakar pembangkit listrik dan untuk mempercepat pembangunan infrastruktur di daerah tersebut.

\section{STUDI LITERATUR}

\section{A. Galangan Kapal}

Galangan kapal (shipyard) adalah sebuah tempat yang dirancang untuk melakukan proses pembangunan kapal (shipbuilding), reparasi kapal (ship repair), dan pemeliharaan kapal (ship maintenance). Produksi kapal dilakukan sesuai dengan spesifikasi yang diinginkan oleh ship owner. 


\section{B. Small Scale LNG Carrier}

Small Scale LNG Carrier merupakan kapal pengangkut LNG yang memiliki kapasitas angkut sampai dengan 40.000 $\mathrm{m}^{3}$, berbeda dengan LNG Carrier pada umumnya yang memiliki kapasitas angkut 125.000 sampai $266.000 \mathrm{~m}^{3}$. Small Scale LNG Carrier bukan hanya LNG Carrier dengan ukuran kapal yang lebih kecil, melainkan dari segi teknis dan ekonomisnya pun berbeda. Small Scale LNG Carrier generasi baru juga memiliki keunggulan dari LNG Carrier pada umumnya, yaitu:

- Dapat membawa produk yang berbeda seperti LNG, ethane, ethylene, propylene, dan petrochemicals lainnya

- Bisa menggunakan terminal besar dan kecil

- Bisa mendistribusikan LNG lebih dekat ke final customer

Small Scale LNG Carrier dapat digunakan untuk membawa produk lain dalam jangka waktu lama dan masih bisa menghasilkan uang. LNG Carrier tidak dapat melakukan hal tersebut, dan akan tetap kehilangan uang jika tidak ada LNG yang dikirim. [2]

Small Scale LNG Carrier juga digunakan untuk daerah terpencil yang perairannya tidak bisa dilewati oleh LNG Carrier dan daerah yang dari segi teknis maupun ekonomis tidak memungkinkan untuk dibangun saluran pipa gas di lokasi tersebut. Gambar 1 merupakan contoh Small Scale LNG Carrier berkapasitas $7.500 \mathrm{~m}^{3}$.

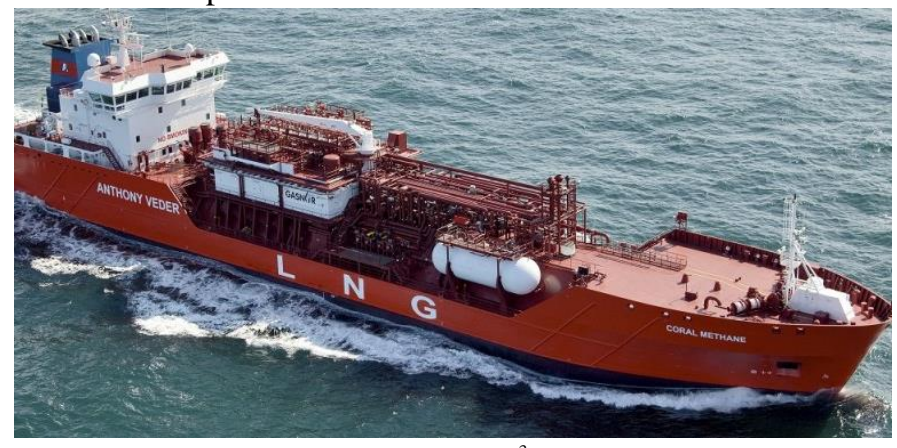

Gambar 1. Small Scale LNG Carrier $7.500 \mathrm{~m}^{3}$

\section{Jenis Tangki Small Scale LNG Carrier}

Small Scale LNG Carrier menggunakan tangki khusus untuk tempat penyimpanan muatannya. Berbeda dengan LNG Carrier yang menggunakan independent tanks type $B$ atau membrane tanks, Small Scale LNG Carrier justru menggunakan independent tanks type $C$, yaitu tangki dengan standar pressure vessel. [4] Penggolongan tangki kapal pengangkut gas ini sesuai dengan regulasi IMO yang diatur dalam International Code for the Construction and Equipment of Ships Carrying Liquefied Gases in Bulk (IGC Code). Independent tanks type $C$ umumnya terbagi menjadi dua jenis, yaitu tangki silinder dan bilobe yang bisa dilihat pada Gambar 2 dan 3.

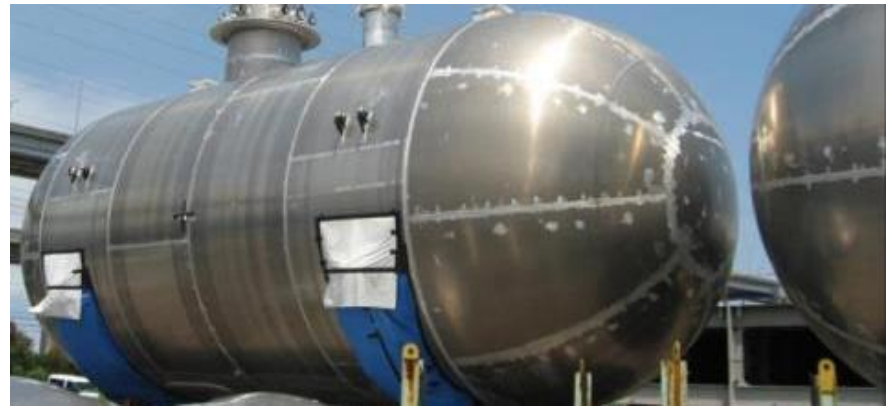

Gambar 2. Tangki Silinder

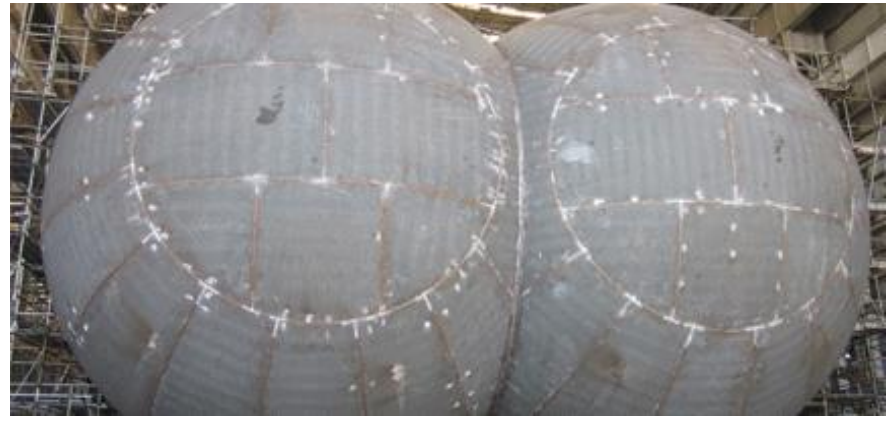

Gambar 3. Tangki Bilobe

\section{METODOLOGI}

Penelitian ini berupa analisa dari segi teknis dan ekonomis mengenai pembangunan galangan kapal Small Scale LNG Carrier untuk perairan Indonesia. Metodologi dari penelitian ini akan dimulai berdasarkan jenis data dan tahapan pelaksanaan.

Selama penelitian, penulis membagi pengerjaan dalam beberapa tahapan, yaitu sebagai berikut:

- Tahap Identifikasi

Pada tahap ini dilaksanakan identifikasi masalah, pencarian sumber informasi (studi literatur dan studi lapangan). Selanjutnya yaitu mengkaji, mengevaluasi, dan mengidentifikasi aspek teknis yang diperlukan dalam pembangunan galangan kapal dari hasil studi literatur dan studi lapangan tersebut.

- Identifikasi Masalah

Pembangunan galangan kapal untuk produksi Small Scale LNG Carrier muncul akibat adanya permasalahan sebagai berikut:

a. Terbatasnya kapal untuk distribusi LNG di Indonesia, sedangkan Indonesia membutuhkan Small Scale LNG Carrier untuk membantu distribusi LNG ke seluruh wilayah Indonesia, khususnya di daerah yang masih kesulitan mendapatkan akses listrik.

b. Belum adanya galangan kapal di Indonesia yang memproduksi Small Scale LNG Carrier.

- Perumusan Masalah dan Tujuan

Dari informasi dan masalah yang teridentifikasi pada tahap sebelumnya, dibuat perumusan masalahnya dan tujuan penelitian yang akan dilakukan.

- Studi Literatur

Studi literatur dilakukan terhadap berbagai referensi terkait topik penelitian. Studi literatur ini dimaksudkan 
untuk memahami konsep dan metode yang tepat untuk menyelesaikan masalah yang telah dirumuskan pada tahap sebelumnya dan untuk mewujudkan tujuan yang dimaksudkan. Studi literatur ini termasuk mencari referensi atas teori-teori terkait atau hasil penelitian yang pernah dilakukan sebelumnya. Adapaun referensi yang diperlukan adalah sebagai berikut:
a. Small Scale LNG Carrier
b. Teknologi dan fasilitas pembangunan Small Scale LNG Carrier
c. Perencanaan tata letak galangan kapal
d. Studi kelayakan
e. Analisa payback period dan return on investment

- Tahap Pengumpulan dan Pengolahan Data

Setelah dapat memahami konsep, penulis melakukan penentuan variabel penelitian yang digunakan, variabel tersebut yaitu:

- Perencanaan fasilitas galangan kapal untuk pembangunan Small Scale LNG Carrier

- Perencanaan tata letak (layout) galangan kapal yang efisien sesuai dengan lokasi galangan kapal yang akan dibangun

- Studi kelayakan akan perencanaan galangan kapal Setelah menentukan variabel, maka langkah selanjutnya, yaitu dilakukan pengumpulan data untuk penelitian ini. Dalam melakukan pengumpulan data, penulis menggunakan metode pengumpulan data secara tidak langsung (sekunder).

Pengumpulan data secara tidak langsung meliputi:

- Data fasilitas galangan kapal untuk pembangunan Small Scale LNG Carrier

- Jumlah kebutuhan Small Scale LNG Carrier di Indonesia

- Tahapan dalam proses pembangunan Small Scale LNG Carrier

- Data kuantitas material yang dibutuhkan untuk pembangunan Small Scale LNG Carrier

- Data lokasi tinjauan galangan kapal

- Struktur organisasi galangan kapal

- Tahap Analisa Lokasi

Setelah mendapatkan data yang diperlukan, maka langkah selanjutnya adalah melakukan tinjauan lokasi lebih lanjut untuk mengetahui kondisi lokasi pembangunan galangan kapal secara pasti dan untuk merencanakan layout galangan kapal sesuai dengan lokasi pembangunan.

- Tahap Analisa Teknis dan Ekonomis

Setelah dilakukan proses pengolahan data, kemudian dilakukan analisa mengenai aspek teknis dan ekonomis. Analisa teknis berupa proses pembangunan Small Scale LNG Carrier mulai dari tahap fabrikasi hingga tahap erection serta fasilitas yang digunakan. Sedangkan untuk analisa ekonomis akan dihitung biaya untuk investasi tanah dan bangunan, investasi fasilitas yang diperlukan, kebutuhan material selama pengerjaan pembangunan Small Scale LNG Carrier, kebutuhan sumber daya manusia yang digunakan, dan studi kelayakan untuk pembangunan galangan kapal Small Scale LNG Carrier.
- Tahap Kesimpulan dan Saran

Dari hasil analisa teknis dan ekonomis akan dapat ditarik kesimpulan mengenai keuntungan dari pembangunan galangan kapal untuk produksi Small Scale LNG Carrier terhadap keuntungan perusahaan. Kemudian diberikan saran-saran yang bisa digunakan untuk pihak investor sehingga dapat memperkirakan besar biaya yang dikeluarkan untuk pembangunan galangan kapal untuk produksi Small Scale LNG Carrier.

\section{POTENSI PASAR SMALL SCALE LNG CARRIER}

\section{A. Segmentasi Konsumen dan Pasar Small Scale LNG Carier}

Di Indonesia Timur, PLN merencanakan pemanfaatan miniLNG untuk pembangkit beban puncak pada sistem-sistem besar di Kalimantan, Sulawesi, Maluku, dan Papua. Namun demikian, tidak menutup kemungkinan mini-LNG juga akan dimanfaatkan untuk pembangkit beban dasar sekaligus beban puncak pada sistem-sistem kecil tersebar. Hal ini dimaksudkan untuk meningkatkan keandalan operasional unit-unit pembangkit. [5]

Adapun rencana pemanfaatan LNG/mini-LNG di Indonesia Tengah - Timur adalah sebagai berikut:

Tabel 1.

Lokasi Lelang Pasokan LNG untuk Pembangkit di Indonesia Tengah

\begin{tabular}{|c|l|l|r|}
\hline No & \multicolumn{1}{|c|}{ Regional } & \multicolumn{1}{|c|}{ Nama Pembangkit } & $\begin{array}{c}\text { Kapasitas } \\
\text { Pembangkit }\end{array}$ \\
\hline 1 & Kalimantan & PLTGU/MGU Kalsel Peaker & $200 \mathrm{MW}$ \\
\hline 2 & Sulawesi & PLTGU Sulsel Peaker & $450 \mathrm{MW}$ \\
\hline 3 & Sulawesi & PLTGU Makassar Peaker & $450 \mathrm{MW}$ \\
\hline 4 & Nusa Tenggara & PLTMG Sumbawa & $50 \mathrm{MW}$ \\
\hline 5 & Nusa Tenggara & PLTMG Waingapu & $10 \mathrm{MW}$ \\
\hline 6 & Nusa Tenggara & PLTMG Bima & $50 \mathrm{MW}$ \\
\hline 7 & Nusa Tenggara & MPP Flores & $20 \mathrm{MW}$ \\
\hline 8 & Nusa Tenggara & PLTMG Maumere & $40 \mathrm{MW}$ \\
\hline 9 & Nusa Tenggara & PLTMG Kupang Peaker & $40 \mathrm{MW}$ \\
\hline 10 & Nusa Tenggara & MPP Lombok & $50 \mathrm{MW}$ \\
\hline
\end{tabular}

\section{ANALISIS TEKNIS PEMBANGUNAN GALANGAN KAPAL SMALL SCALE LNG CARRIER}

\section{A. Perencanaan Lokasi Galangan Kapal}

Lokasi pertama yang direncanakan untuk pembangunan galangan kapal Small Scale LNG Carrier berada di Desa Sidokelar, Kecamatan Paciran, Kabupaten Lamongan. Sedangkan lokasi kedua berada di Desa Socah, Kabupaten Bangkalan, Madura.

Pembobotan dilakukan untuk menghasilkan pilihan lokasi yang akan menjadi pertimbangan untuk dibangunnya galangan kapal. Pembobotan dilakukan dengan menggunakan metode pembobotan Analytical Hierarchy Process (AHP). Konsep dasar AHP adalah penggunaan matriks pairwise comparison (matriks perbandingan berpasangan) untuk menghasilkan bobot relatif antar kriteria maupun alternatif. [6] Tabel 2 merupakan perhitungan pembobotan untuk pemilihan lokasi galangan kapal. 
Tabel 2.

Perhitungan Pembobotan

\begin{tabular}{|c|c|c|c|c|c|c|c|}
\hline Pertimbangan & Bobot & Sub Pertimbangan & Bobot & $\begin{array}{c}\text { Skor } \\
\text { Lokasi } 1\end{array}$ & $\begin{array}{c}\text { Skor } \\
\text { Lokasi } 2\end{array}$ & $\begin{array}{l}\text { Penilaian } \\
\text { Lokasi } 1\end{array}$ & $\begin{array}{l}\text { Penilaian } \\
\text { Lokasi } 2\end{array}$ \\
\hline \multirow{2}{*}{ Kondisi lahan } & \multirow{2}{*}{0.175} & Kemampuan lahan & 0.087 & 3 & 2 & 0.052 & 0.035 \\
\hline & & Pengunaan lahan & 0.087 & 3 & 2 & 0.052 & 0.035 \\
\hline $\begin{array}{c}\text { Ketersediaan } \\
\text { tenaga kerja }\end{array}$ & 0.068 & $\begin{array}{c}\text { Ketersediaan tenaga } \\
\text { kerja }\end{array}$ & 0.068 & 1 & 1 & 0.034 & 0.034 \\
\hline \multirow{3}{*}{$\begin{array}{c}\text { Ketersediaan } \\
\text { bahan baku }\end{array}$} & \multirow{3}{*}{0.109} & Kuantitas bahan baku & 0.036 & 1 & 1 & 0.018 & 0.018 \\
\hline & & Kontinuitas bahan baku & 0.036 & 1 & 1 & 0.018 & 0.018 \\
\hline & & Jarak bahan baku & 0.036 & 3 & 2 & 0.022 & 0.014 \\
\hline Pemasaran & 0.124 & $\begin{array}{l}\text { Adanya galangan kapal } \\
\text { dan pesaing }\end{array}$ & 0.124 & 2 & 3 & 0.050 & 0.074 \\
\hline $\begin{array}{l}\text { Rencana tata } \\
\text { ruang }\end{array}$ & 0.039 & Rencana tata ruang & 0.039 & 1 & 1 & 0.020 & 0.020 \\
\hline Modal & 0.245 & Harga tanah per $\mathrm{m}^{2}$ & 0.245 & 2 & 3 & 0.098 & 0.147 \\
\hline \multirow{3}{*}{$\begin{array}{l}\text { Kecukupan } \\
\text { infrastruktur }\end{array}$} & \multirow{3}{*}{0.241} & Kecukupan listrik & 0.08 & 1 & 1 & 0.040 & 0.040 \\
\hline & & Kecukupan air bersih & 0.08 & 1 & 1 & 0.040 & 0.040 \\
\hline & & Kecukupan akses jalan & 0.08 & 1 & 1 & 0.040 & 0.040 \\
\hline Total & 1 & Total & 1 & 20 & 19 & 0.477 & 0.521 \\
\hline
\end{tabular}

Dari hasil perhitungan Tabel 2, maka didapatkan lokasi 2 sebagai lokasi yang dipilih untuk pembangunan galangan kapal Small Scale LNG Carrier, yaitu di Desa Socah, Kabupaten Bangkalan, Madura.

\section{B. Analisa Kebutuhan dan Kapasitas Tangki Small Scale LNG Carrier}

Kebutuhan Small Scale LNG Carrier beserta dengan kapasitas tangkinya didapatkan dari perhitungan pasar LNG di Indonesia untuk proyek pemerintah, yaitu program pembangkit listrik 35.000 MW yang dirancang melalui RUPTL PLN 20172026. Dengan menggunakan LNG sebagai salah satu bahan bakar pembangkit listrik, kebutuhan Small Scale LNG Carrier beserta dengan kapasitas tangkinya dapat dicari dengan cara mengkonversi kapasitas daya pembangkit listrik, yaitu megawatt (MW) menjadi kapasitas bahan bakar LNG dalam bentuk volume meter kubik $\left(\mathrm{m}^{3}\right)$. Untuk lebih jelasnya dapat dilihat pada Tabel 3 .

Tabel 3.

Satuan Proses Konversi LNG dari MW ke $\mathrm{m}^{3}$

\begin{tabular}{|l|r|l|l|}
\hline \multicolumn{4}{|c|}{ Satuan untuk Konversi LNG } \\
\hline 1 MW & 0.2 & MMSCFD & (Million Standard Cubic Feet per Day) \\
\hline 1 MMSCFD & 18 & TPD & (Ton per Day) \\
\hline 1 TPD & 52 & MMBTU & (Million British Thermal Units) \\
\hline $1 \mathrm{~m}^{3}$ LNG & 21.2 & MMBTU & \\
\hline
\end{tabular}

Perhitungan ini meliputi aspek durasi pelayaran dan bongkar muat. Contoh yang digunakan untuk perhitungan kapasitas tangki kali ini adalah berdasarkan kebutuhan LNG pada cluster Kalbar-Bangka-Belitung. Cluster ini mendapat pasokan dari LNG Plant Bontang. Maka jarak rute pelayaran dimulai dari LNG Plant Bontang sebagai tempat sumber pasokan LNG menuju PLTMG Pontianak Peaker, MPP Kalbar, MPP Bangka, dan MPP Belitung seperti yang bisa dilihat pada Tabel 4. Pengukuran jarak pelayaran menggunakan aplikasi dari MarineCircle dengan asumsi kecepatan 15 knots.
Tabel 4.

Perhitungan Kapasitas Tangki

\begin{tabular}{|l|c|c|c|}
\hline \multicolumn{1}{|c|}{ Nama Pembangkit } & MW & $\mathbf{m}^{\mathbf{3}}$ & $\mathbf{m}^{\mathbf{3}} \mathbf{x} \mathbf{8 . 1 4}$ hari \\
\hline PLTMG Pontianak Peaker & 100 & 883 & 7181 \\
\hline MPP Kalbar & 100 & 883 & 7181 \\
\hline MPP Bangka & 50 & 442 & 3591 \\
\hline MPP Belitung & 25 & 221 & 1795 \\
\hline Total & 275 & 2428 & 19749 \\
\hline
\end{tabular}

Jadi kapasitas tangki Small Scale LNG Carrier untuk cluster Kalbar-Bangka-Belitung didapat sebesar $19.749 \mathrm{~m}^{3}$. Kapasitas tangki akan dibulatkan menjadi $20.000 \mathrm{~m}^{3}$ untuk mempermudah pembuatan tangki pada saat proses produksi.

\section{Perencanaan Fasilitas Produksi}

1. Analisa Kebutuhan Baja untuk Produksi Small Scale LNG Carrier

Dalam analisa kebutuhan material pelat baja dan pipa untuk pembangunan Small Scale LNG Carrier dibutuhkan metode pendekatan untuk mendapatkan beban kerja (work load) yang kemudian didapatkan kebutuhan material per hari. Pendekatan dilakukan dengan menggunakan referensi dari desain kapal Wärtsilä WSD50 20K dengan kapasitas sebesar $20.000 \mathrm{~m}^{3}$. Data ukuran utama dan steel weight WSD50 20K dapat dilihat pada tabel 5 .

Tabel 5.

Data Ukuran Utama dan Steel Weight

\begin{tabular}{|c|c|c|c|}
\hline Dimensi & Ukuran & \multicolumn{2}{|c|}{ Wärtsilä WSD50 20K Steel Weight } \\
\hline $\begin{array}{l}\text { LOA } \\
\text { LPP }\end{array}$ & $\begin{array}{c}147,25 \mathrm{~m} \\
138,7 \mathrm{~m}\end{array}$ & Bagian & Steel Weight (ton) \\
\hline B & $25,3 \mathrm{~m}$ & \multirow{2}{*}{ Hull } & \multirow[t]{2}{*}{7467} \\
\hline $\mathrm{H}$ & $17,6 \mathrm{~m}$ & & \\
\hline $\mathrm{T}$ & $7,8 \mathrm{~m}$ & Cargo Tank & 1941 \\
\hline DWT & 12.500 ton & \multirow{2}{*}{ Total } & \multirow{2}{*}{9408} \\
\hline Vs & 15 knots & & \\
\hline
\end{tabular}

Untuk pembagian total kebutuhan berat material untuk pembangunan Small Scale LNG Carrier dapat dilihat pada Tabel 6. Dengan ukuran $50 \mathrm{~m}$ x $40 \mathrm{~m}=2000 \mathrm{~m}^{2}$ maka luas gudang penyimpanan telah mencukupi untuk seluruh kebutuhan material pelat, profil, dan pipa.

Tabel 6.

Total Kebutuhan Material

\begin{tabular}{|c|c|c|c|}
\hline Kebutuhan & Berat (ton) & $\begin{array}{c}\text { Lama waktu } \\
\text { pembangunan }\end{array}$ & $\begin{array}{c}\text { Total berat } \\
\text { (ton) }\end{array}$ \\
\hline Pelat & 5644,8 & 24 bulan & 5644,8 \\
\hline Profil & 2822,4 & 24 bulan & 2822,4 \\
\hline Pipa & 940,8 & 24 bulan & 940,8 \\
\hline \multicolumn{3}{|c|}{ Total } & 9408 \\
\hline
\end{tabular}

2. Penentuan Jumlah Fasilitas Produksi

Penentuan jumlah peralatan yang dibutuhkan pada masingmasing bengkel dihitung berdasarkan pada beban kerja yang harus dipenuhi oleh masing-masing bengkel produksi, dalam durasi waktu yang telah ditentukan dan/atau diasumsikan. Dalam perhitungan jumlah fasilitas produksi, direncanakan kapasitas produksi pada masing-masing bengkel dan durasi pengerjaan yang dibutuhkan seperti pada Tabel 7 . 
Tabel 7.

Kapasitas Produksi pada Setiap Bengkel

\begin{tabular}{|c|c|c|c|c|c|}
\hline Bengkel & $\begin{array}{c}\text { Durasi } \\
\text { Pengerjan }\end{array}$ & $\begin{array}{c}\text { Kapasitas } \\
\text { Produksi ton/hari }\end{array}$ & $\begin{array}{c}\text { Beban Kerja } \\
\text { Pelat ton/hari }\end{array}$ & $\begin{array}{c}\text { Beban Kerja } \\
\text { Profil ton/hari }\end{array}$ & $\begin{array}{c}\text { Beban Kerja } \\
\text { Pipa ton/hari }\end{array}$ \\
\hline Preparation & 15 bulan & 31,360 & 18,316 & 9,408 & 3,136 \\
\hline Fabrication & 17 bulan & 27,671 & 16,602 & 8,301 & 2,767 \\
\hline Sub Assembly & 19 bulan & 24,758 & 14,855 & 7,427 & 2,476 \\
\hline Assembly & 19 bulan & 24,758 & 14,855 & 7,427 & 2,476 \\
\hline Erection & 17 bulan & 27,671 & 16,602 & 8,301 & 2,767 \\
\hline
\end{tabular}

Dengan besar beban kerja untuk pelat perhari sebesar 18,816 ton/hari, maka untuk pemenuhan beban kerja tersebut direncanakan plate straightening machine dengan spesifikasi seperti pada Tabel 8.

Tabel 8.

Spesifikasi Plate Straightening Machine

\begin{tabular}{|l|l|}
\hline \multicolumn{2}{|c|}{ Specification } \\
\hline Type & Plate Straightening Machine \\
\hline Max. Material Thickness & $20 \mathrm{~mm}$ \\
\hline Max. Material Width & $3200 \mathrm{~mm}$ \\
\hline Speed & $50 \mathrm{~min} /$ ton \\
\hline
\end{tabular}

Berikut ini merupakan perhitungan untuk menentukan jumlah plate straightening machine yang dibutuhkan:

Lama pengerjaan $=1$ hari

Waktu pekerja $=6 \mathrm{jam} / \mathrm{hari}$

Kecepatan mesin $=50 \mathrm{menit} / \mathrm{lembar}$

$=0,8 \mathrm{jam} / \mathrm{lembar}$

Ukuran pelat $\quad=1800 \mathrm{~mm} \times 14 \mathrm{~mm}$

Panjang pelat $\quad=6 \mathrm{~m}$

Berat pelat $\quad=1,187$ ton/lembar

Kebutuhan pelat $=23$ lembar

Panjang total pelat $=138 \mathrm{~m}$

Beban mesin $(\mathrm{T}) \quad=6 \mathrm{jam} / \mathrm{hari}$

Maka, dalam 1 hari:

Pelat selesai $\quad=138 \mathrm{~m}$

$=23$ lembar

Kebutuhan mesin =

$$
\mathrm{M}=\mathrm{W} /(\mathrm{T} \times \mathrm{t}) \times \mathrm{V}
$$

Dimana:

$\mathrm{M}=$ Kebutuhan mesin

$\mathrm{W}=$ Jumlah lembar pelat selesai dalam 1 hari

$\mathrm{T}=$ Beban mesin

$\mathrm{t}=$ Waktu pekerja per hari

$\mathrm{v}=$ Kecepatan mesin jam/lembar

$$
\begin{gathered}
\mathrm{M}=23 /(6 \times 6) \times 0,8 \\
\mathrm{M}=0,532 \\
\mathrm{M} \approx 1
\end{gathered}
$$

Maka jumlah plate straightening machine yang dibutuhkan adalah sebanyak 1 unit. Sedangkan untuk operator mesin direncanakan untuk setiap mesin memiliki 1 operator. Dilakukan perhitungan yang sama untuk menentukan jumlah mesin yang dibutuhkan pada setiap bengkel.

\section{Perencanaan Tata Letak Galangan Kapal}

Dengan memperhitungkan luas gudang penyimpanan material, luas bengkel persiapan, bengkel fabrikasi, bengkel sub-assembly, bengkel assembly, bengkel blasting dan painting, bengkel machinery, bengkel piping, bengkel electrical, bengkel outfitting, serta dimensi kapal yang akan dibangun nantinya di graving dock, maka dapat direncanakan tata letak (layout) galangan kapal yang optimal dan efisien. Didapatkan perencanaan luas galangan kapal dengan ukuran $270 \mathrm{~m}$ x $213 \mathrm{~m}$, untuk fasilitas sarana pengedokan menggunakan graving dock sebanyak satu buah. Pemilihan ini didasarkan pada analisa teknis dan ekonomis yang telah dilakukan pada masing-masing fasilitas pengedokan. Berdasarkan fasilitas pengedokan yang digunakan, maka direncanakan pembangunan Small Scale LNG Carrier sebanyak satu unit untuk setiap dua tahun. Dari analisa teknis yang telah dilakukan, maka perencanaan layout galangan kapal dapat dilakukan plotting pada lokasi tersebut. Berikut pada Gambar 4 merupakan layout galangan kapal yang direncanakan dalam bentuk 2D.

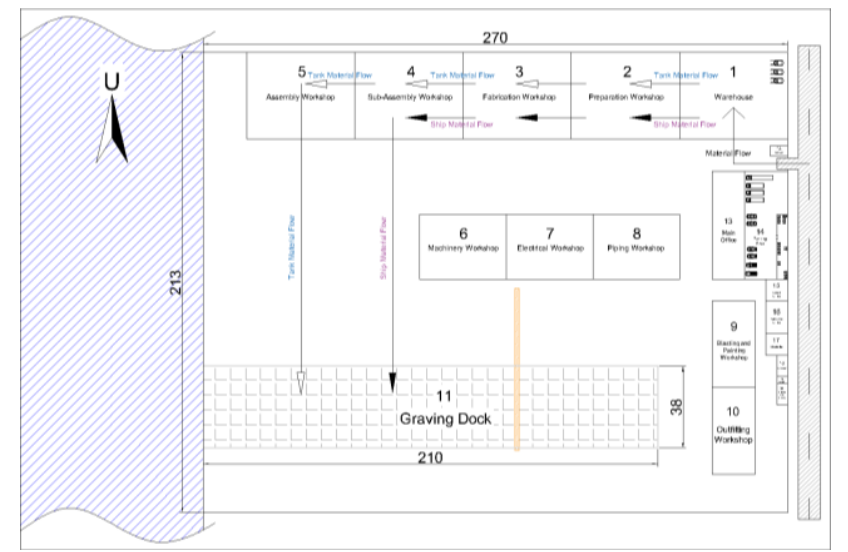

Gambar 4. Layout Galangan Kapal 2D

Gambar 5 merupakan layout galangan kapal Small Scale LNG Carrier dalam bentuk 3D.

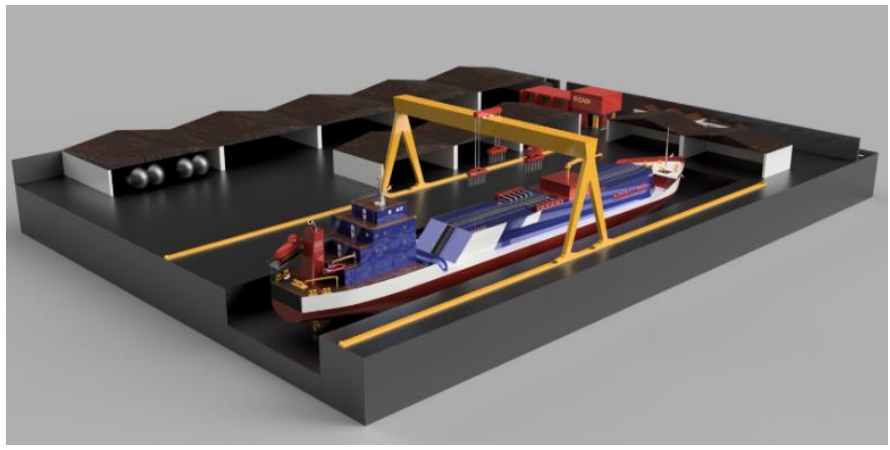

Gambar 5. Layout Galangan Kapal 3D

\section{ANALISA EKONOMIS PEMBANGUNAN GALANGAN KAPAL SMALL SCALE LNG CARRIER}

\section{A. Analisa Nilai Investasi}

Setelah mendapatkan estimasi besarnya biaya yang dikeluarkan untuk persiapan dan manajemen, pembebasan lahan, pembuatan bangunan serta pengadaan peralatan fasilitas penunjang pada pembangunan galangan kapal untuk produksi Small Scale LNG Carrier, sehingga didapat total investasi awal yang dibutuhkan untuk pembangunan galangan kapal sebesar Rp344.232.163.768 dengan rincian yang bisa dilihat pada Tabel 9. 
Tabel 9

Estimasi Nilai Total Investasi

\begin{tabular}{clr}
\hline \hline No & \multicolumn{1}{c}{ Biaya Investasi } & \multicolumn{1}{c}{ Harga } \\
\hline 1 & Total Harga Tanah & 56.317 .200 .000 \\
2 & Total Harga Bangunan & 214.463 .100 .000 \\
3 & Biaya Utilitas & 20.100 .000 .000 \\
4 & Total Harga Peralatan & 45.420 .148 .880 \\
5 & Perawatan Peralatan per Tahun (10\%) & 4.542 .014 .888 \\
& $\quad$ Total Biaya Investasi & $\mathbf{3 4 0 . 8 4 2 . 4 6 3 . 7 6 8}$ \\
\hline
\end{tabular}

Total pengeluaran dalam satu proyek juga diperhatikan karena digunakan sebagai acuan untuk mencari keuntungan perusahaan. Pengeluaran yang harus dikeluarkan perusahaan setiap tahunnya adalah sebagai berikut:

1. Biaya operasional

Pada biaya operasional pembangunan galangan kapal Small Scale LNG Carrier terdiri dari:

$$
\begin{array}{ll}
\text { - } \text { Biaya Langsung } & =\text { Rp189.609.279.309,- } \\
\text { - } \text { Biaya Perawatan } & =R p 193.000 .000,- \\
\text { - Biaya Tidak Langsung } & =\text { Rp6.408.000.000,- }
\end{array}
$$

\section{Depresiasi}

Depresiasi atau penyusutan dalam akuntansi adalah alokasi sistematis jumlah yang dapat disusutkan dari suatu aset selama umur manfaatnya. Penerapan depresiasi akan mempengaruhi laporan keuangan, termasuk penghasilan kena pajak suatu perusahaan. Untuk menghitung depresiasi digunakan nilai inflasi sebesar $6 \%$. Untuk lebih jelasnya dapat dilihat pada Tabel 10.

Tabel 10.

Nilai Depresiasi Investasi

\begin{tabular}{|c|l|c|c|}
\hline \multirow{2}{*}{\begin{tabular}{c}
\multirow{2}{*}{ Life } \\
Time
\end{tabular}} & \multirow{2}{*}{ Deskripsi investasi } & \multicolumn{2}{|c|}{ Tahun } \\
\cline { 3 - 4 } & & $\mathbf{2 0 1 8}$ & $\mathbf{2 0 1 9}$ \\
\cline { 3 - 4 } & & $\mathbf{0}$ & $\mathbf{1}$ \\
\hline 10 & Graving Dock 30.000 DWT & 159.600 .000 .000 & 28.581 .929 .237 \\
\hline 20 & Gudang Penyimpanan & 6.000 .000 .000 & 962.140 .642 \\
\hline 20 & Bengkel Persiapan & 6.000 .000 .000 & 962.140 .642 \\
\hline 20 & Bengkel Fabrikasi & 6.000 .000 .000 & 962.140 .642 \\
\hline 20 & Bengkel Sub-Assembly & 6.000 .000 .000 & 962.140 .642 \\
\hline
\end{tabular}

3. Uang Keluar Berdasarkan Aktivitas Keuangan

- Pembayaran Angsuran Pinjaman

- Pembayaran Angsuran Bunga Pinjaman

Pengembalian pinjaman dengan Estimated Interest Loans sebesar 11\%. Untuk lebih jelasnya dapat dilihat pada Tabel 11. Tabel 11.

Uang Keluar Berdasarkan Aktivitas Keuangan

\begin{tabular}{|c|c|c|c|c|}
\hline $\begin{array}{c}\text { Tahun } \\
\text { ke- }\end{array}$ & $\begin{array}{c}\text { Bunga Pinjaman } \\
\text { (Juta Rupiah) }\end{array}$ & $\begin{array}{c}\text { Angsuran (Juta } \\
\text { Rupiah) }\end{array}$ & $\begin{array}{c}\text { Pembayaran (Juta } \\
\text { Rupiah) }\end{array}$ & $\begin{array}{c}\text { Sisa Pinjaman (Juta } \\
\text { Rupiah) }\end{array}$ \\
\hline 0 & & & & 204.505 .478 .261 \\
\hline 1 & 22.495 .602 .609 & $5.944 .000 .710,8$ & 28.439 .603 .319 & 198.561 .477 .550 \\
\hline 2 & 21.841 .762 .531 & $6.597 .840 .789,0$ & 28.439 .603 .319 & 191.963 .636 .761 \\
\hline 3 & 21.116 .000 .044 & $7.323 .603 .275,8$ & 28.439 .603 .319 & 184.640 .033 .485 \\
\hline
\end{tabular}

4. Pajak

Earning Before Tax (EBT) adalah uang yang disimpan oleh perusahaan sebelum dikurangi karena harus membayar pajak. Dengan besar pajak $21 \%$ per tahun dari EBT dapat dilihat rinciannya pada Tabel 12 .
Tabel 12.

Besar Pajak per Tahun (dalam Ribu Rupiah)

\begin{tabular}{|c|c|c|c|c|c|}
\hline \multirow{2}{*}{\begin{tabular}{c} 
Description \\
\cline { 2 - 6 }
\end{tabular}} & \multicolumn{5}{|c|}{ Years to Year } \\
\hline $\begin{array}{c}\text { EBT (Earning Before } \\
\text { Tax) }\end{array}$ & & $\mathbf{0}$ & $\mathbf{2}$ & $\mathbf{1 9}$ & $\mathbf{2 0}$ \\
\hline Pajak 21 \% & & $(8.028 .614)$ & 28.741 .385 & 188.165 .001 & 199.706 .185 \\
\hline
\end{tabular}

Untuk estimasi pendapatan galangan kapal Small Scale LNG Carrier dapat dilihat pada Tabel 13.

\begin{tabular}{|c|c|c|c|c|c|c|c|c|c|c|}
\hline \multirow{3}{*}{ Fasilitas } & \multirow{3}{*}{$\begin{array}{l}\text { Waktu } \\
\text { Kerja } \\
\text { (bulan) }\end{array}$} & \multirow{3}{*}{$\begin{array}{l}\text { Nilai } \\
\text { Project }\end{array}$} & \multirow{3}{*}{$\begin{array}{c}\text { Kenaikan } \\
\text { Pendapatan/ } / \\
\text { Tahun. (\%) }\end{array}$} & \multicolumn{7}{|c|}{ Tahun ke- } \\
\hline & & & & $50 \%$ & $100 \%$ & $50 \%$ & $100 \%$ & $50 \%$ & $50 \%$ & $100 \%$ \\
\hline & & & & 1 & 2 & 3 & 4 & 5 & 19 & 20 \\
\hline $\begin{array}{c}G D \\
\text { GD } \\
(30.000 \\
\text { DWT }\end{array}$ & 24 & 600.000 & $5 \%$ & 300.000 & 300.000 & 315.000 & 330.750 & 347.288 & 687.605 & 721.986 \\
\hline$d \eta$ & aving & & an bas & 300.000 & 300.000 & 315.000 & 330.750 & 347.288 & 687.605 & 721.986 \\
\hline
\end{tabular}

Tabel 13.

Estimasi Pendapatan Galangan Kapal (dalam Juta Rupiah)

Proyek pembangungan Small Scale LNG Carrier mempunyai nilai sekitar 600 milyar rupiah dengan target pembangunan Small Scale LNG Carrier sebanyak satu unit setiap dua tahun.

\section{B. Analisa Kelayakan Investasi}

Pada Tabel 6.14 menunjukkan bahwa waktu investasi untuk pembangunan galangan kapal Small Scale LNG Carrier kembali pada tahun ke-9 bulan ke-1,5. Dengan nilai Net Present Value (NPV) sebesar Rp82,3 miliar, Internal Rate of Return (IRR) sebesar $13,41 \%$ lebih besar dari bunga bank yang telah ditetapkan yakni $11 \%$, sehingga investasi pembangunan galangan kapal Small Scale LNG Carrier layak dilakukan.

\begin{tabular}{|c|c|c|c|}
\hline No. & Deskripsi & Nilai & Unit \\
\hline 1 & Jumlah Komulatif FCF $x$ Rumus PV = NPV & 82.289 .132 & (ribu rupiah) \\
\hline 2 & Pengembalian Invest. $(+)$ : Invest. $=$ IRR & 13,41 & $\%$ \\
\hline 3 & Rata-rata NPV : Invest. = ROI & 22,00 & $\%$ \\
\hline \multirow{3}{*}{4} & \multirow{3}{*}{ Payback Periode } & 9,13 & tahun \\
\hline & & 9 & tahun \\
\hline & & 1,5 & bulan \\
\hline & Go Project / Layak & & \\
\hline
\end{tabular}
Tabel 14.

Nilai NPV, IRR, ROI, dan Payback Periode

\section{KESIMPULAN DAN SARAN}

Setelah dilakukan perhitungan dan penelitian, maka kesimpulan dari penelitian ini adalah sebagai berikut:

1. Potensi pasar untuk Small Scale LNG Carrier cukup tinggi karena berdasarkan analisa yang telah dilakukan penulis pada RUPTL PLN 2017-2026, Indonesia membutuhkan Small Scale LNG Carrier berjumlah 26 unit kapal dengan kapasitas yang berbeda-beda. Oleh karena itu, pembangunan galangan kapal Small Scale LNG Carrier di Indonesia layak dilakukan karena selain belum adanya galangan kapal dalam negeri yang mampu untuk memproduksinya, kebutuhan pasar untuk kapal tersebut di Indonesia juga cukup tinggi.

2. Dengan nilai Internal Rate of Return (IRR) sebesar 13,36\% lebih besar dari bunga bank yang telah ditetapkan yakni $11 \%$, sehingga investasi pembangunan galangan kapal Small Scale LNG Carrier layak dilakukan.

Saran yang dapat diberikan untuk pengembangan penelitian ini adalah sebagai berikut:

1. Perlu adanya pemahaman lebih lanjut mengenai teknologi Small Scale LNG Carrier baik dari segi sistem maupun 
dari tangkinya serta perlu adanya Standard Operating Procedure (SOP) dan kualitas kontrol yang benar dan tepat agar kualitas dari material dan finishing tetap terjaga.

2. Perlu adanya dukungan dari pihak pemerintah untuk mempercepat proyek pembangunan Small Scale LNG baik dari segi transportasi maupun infrastrukturnya seperti fasilitas regasifikasi, liquefaction, dan lain-lain.

\section{DAFTAR PUSTAKA}

[1] G. Press, "Gas LNG Europe," 2014.

[2] S. S. L. S. Consultant, "Small Scale LNG," http://www.smalllng.com, 2012. [Online]. Available: http://www.small-lng.com.

[3] K. O. \& M. T. Centre, Small Scale LNG Carriers. 2014.

[4] American Bureau of Shipping (ABS), Gas Carriers: Arrangements \& Characteristics. 2014

[5] P. P. (Persero), "Rencana Usaha Penyediaan Listrik PT Perusahaan Listrik Negara (Persero) Tahun 2017 s.d. 2026,” 2017.

[6] T. . Saaty, "The Analytic Hierarchy Process: Planning, Priority Setting," Pennsylvania State University, 1990. 